2017 - Volume: 18 Number: 5

Page: 1008 - 1017

DOI: $10.18038 /$ aubtda. 332155

Received: 01 August 2017 Revised: 17 September 2017 Accepted: 03 0ctober 2017

\title{
MECHANICAL BEHAVIOR OF FLY ASH OR CEMENT STABILIZED SAND-BENTONITE MIXTURES EXPOSED TO FREEZE-THAW ACTION
}

\author{
AIper SEZER ${ }^{1, *}$, Nazar TANRINIAN ${ }^{1}$, Yunus Emre ADAMCIL ${ }^{1}$ \\ ${ }^{1}$ Civil Engineering Department, Faculty of Engineering, Ege University, 35100, İzmir, Turkey
}

\begin{abstract}
In construction of landfills, embankments and transportation structures, use of clay-sand mixtures are commonly preferred. To provide stability and enhance engineering properties, stabilization with chemical admixtures is a reasonable approach. Unfortunately, freeze-thaw effect is a significant problem controlling the mechanical behavior of soils in cold regions. Since past studies on strength behavior of clay-sand mixtures stabilized using fly ash or cement exposed to freeze-thaw action is limited, in this study, an experimental framework was used to investigate the effects of clay content, admixture type, number of freeze-thaw cycles on strength of clay-sand mixtures including pozzolanic cement or class $\mathrm{C}$ fly ash. Sand specimens including 4, 8, 12 and $16 \%$ bentonite by weight were stabilized with 3, 6, $9 \%$ pozzolanic cement and 5, 10, 15 and $20 \%$ class $\mathrm{C}$ fly ash by weight, specimens were prepared at optimum water content of mixtures. The specimens were then subjected to 1, 3 and 10 freeze-thaw cycles after 28 days of curing period. Freeze-thaw resistance of specimens was determined by carrying out unconfined compression tests. Experimental results revealed that, under certain curing conditions, cement and fly ash stabilization positively affects the strength of sand-bentonite mixtures and dominates the negative effects of freeze-thaw action. As expected, specimens stabilized with pozzolanic cement provided higher freeze-thaw resistance compared to those amended with fly ash. Besides, analysis of secant modulus values revealed that, cement stabilized specimens showed a more rigid behavior after freeze-thaw action.
\end{abstract}

Keywords: Sand-bentonite mixtures, Freeze-thaw effect, Cement, Fly ash, Stabilization

\section{INTRODUCTION}

Artificial blends of sand-clay mixtures are used in many geotechnical engineering applications including transportation structures, landfills and embankments. In such projects, stabilization with chemical admixtures is a commonly preferred method for enhancing the stability and mechanical properties of the ground mixtures. On the other hand, freeze-thaw action (FTA) is one of the factors which may adversely affect on soil properties. Particularly, this phenomenon is effective on mechanical behavior and stability of saturated shallow stabilized soil layers. Cyclic freezing-thawing action changes the volume of pore water and causes crack formation \& propagation and subsequent shrinkage in soil.

Cement is a frequently used admixture in construction of highways, landfills and slope stabilization providing high wetting-drying and freeze-thaw (FT) resistance [1-3]. Fly ash, which is a by-product of coal combustion process, is a waste material used as a binder in soil stabilization [4]. It is currently used in geotechnical applications as a filler \& binding material in deep and shallow soil improvement [5]. Many studies in literature stressed that fly ash provides a significant increase in strength of soils used in contents varying between 5\% and 30\% [5-7]. Unver [8], compared the performances of class C and $\mathrm{F}$ fly ashes as stabilizers and stated that stabilization with class $\mathrm{C}$ fly ash provided higher strength. Studies on freeze-thaw behavior of soils revealed that decrease in strength was more evident by increasing number of cycles [9-13]. In this scope, Yarbasi et al. [10] investigated the freeze-thaw resistance of sand-gravel mixtures stabilized with various combinations of cement, lime, silica fume and fly ash. The authors stressed that the use of waste materials with cement admixture would be 
beneficial in terms of economy. Erol [14] experimentally proved that strength of silt samples of variable water content was improved by increasing in number of cycles. On the other hand, for specimens of constant water content, strength is decreased by increasing number of freeze-thaw cycles.

In this study, mechanical behavior of sand-clay mixtures stabilized with cement and class $\mathrm{C}$ fly ash exposed to freeze-thaw action was investigated, under certain freeze-thaw conditions. The variation of strength and secant modulus were comparatively investigated.

\section{MATERIALS AND METHOD}

\subsection{Materials}

Sand obtained from Aydinlar Madencilik was artificially blended with bentonite obtained from ESAN firm. The grain size distribution of sand was determined as given in Figure 1. Atterberg limits of bentonite were determined in accordance with ASTM D4318 standard. Liquid limit (LL), plastic limit (PL) and plasticity index (PI) were determined as 190\%, 76\% and 114\%, respectively.

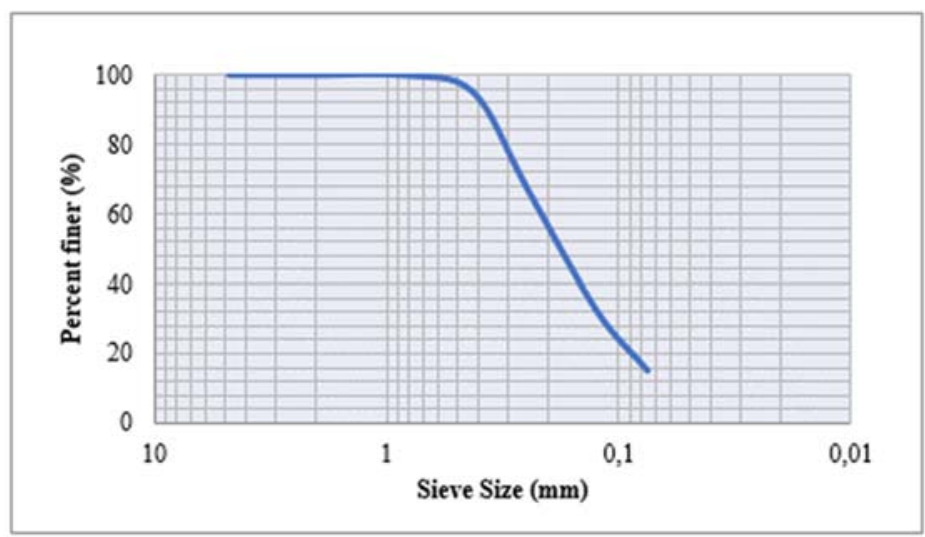

Figure 1. Grain size distribution of sand

Chemical properties of bentonite were provided by the manufacturer (Table 1).

Table 1. Chemical properties of bentonite

\begin{tabular}{lc}
\hline Component & Content(\%) \\
\hline $\mathrm{SiO}_{2}$ & 73.00 \\
$\mathrm{Al}_{2} \mathrm{O}_{3}$ & 13.00 \\
$\mathrm{Fe}_{2} \mathrm{O}_{3}$ & 0.70 \\
$\mathrm{CaO}$ & 1.10 \\
$\mathrm{MgO}$ & 3.00 \\
$\mathrm{TiO}_{2}$ & 0.05 \\
$\mathrm{Na}_{2} \mathrm{O}$ & 0.25 \\
$\mathrm{~K}_{2} \mathrm{O}$ & 1.10 \\
$\mathrm{LOI}$ & 6.50 \\
\hline
\end{tabular}

Pozzolanic cement and class $\mathrm{C}$ fly ash (C-FA) were used as admixtures for stabilization. The type of the pozzolanic cement used according to TS EN 197 is a CEM IV/B (P) $32.5 \mathrm{~N}$ cement produced by Batısöke company. A natural type of pozzolan (trass) is included at a level ranging between $36-55 \%$ (by weight). Minor additional ingredients content is maximum 5\%. Fly ash is obtained from Soma power plant. Chemical properties of pozzolanic cement and fly ash were given in Table 2. Physical properties of fly ash is given in Table 3 . 
Sezer et al. / Anadolu Univ. J. of Sci. and Technology A - Appl. Sci. and Eng. 18 (5) - 2017

Table 2. Chemical properties of cement and fly ash used in this study

\begin{tabular}{lcc}
\hline \multirow{2}{*}{ Component } & \multicolumn{2}{c}{ Content } \\
\cline { 2 - 3 } & Cement & Fly ash \\
\hline $\mathrm{SiO}_{2}(\%)$ & 25.02 & 39.62 \\
$\mathrm{Al}_{2} \mathrm{O}_{3}(\%)$ & 7.57 & 18.95 \\
$\mathrm{Fe}_{2} \mathrm{O}_{3}(\%)$ & 3.69 & 4.06 \\
$\mathrm{CaO}(\%)$ & 53.27 & 27.67 \\
$\mathrm{MgO}(\%)$ & 1.33 & 1.95 \\
$\mathrm{SO}(\%)$ & 3.37 & 3.83 \\
$\mathrm{Na}_{2} \mathrm{O}(\%)$ & 0.72 & 0.66 \\
$\mathrm{~K} 2 \mathrm{O}(\%)$ & 0.96 & 1.33 \\
$\mathrm{LOI}(\%)$ & 3.56 & 0.97 \\
$\mathrm{Specific} \mathrm{surface}\left(\mathrm{cm}^{2} / \mathrm{g}\right)$ & 3700 & 2460 \\
\hline
\end{tabular}

Table 3. Physical properties of Class C fly ash

\begin{tabular}{lc}
\hline Property & Fly Ash \\
\hline Specific gravity & 2.53 \\
Percent coarser than $0.090 \mathrm{~mm} \mathrm{( \% )}$ & 18.9 \\
Percent coarser than $0.045 \mathrm{~mm} \mathrm{( \% )}$ & 41.6 \\
\hline
\end{tabular}

\subsection{Preparation of Specimens}

Soil mixtures were prepared by mixing bentonite with sand at varying contents of $4,8,12$ and $16 \%$ by weight. Standard Proctor Tests were conducted to find the optimum moisture content of mixtures. The compaction curves were obtained as seen in Figure 2.

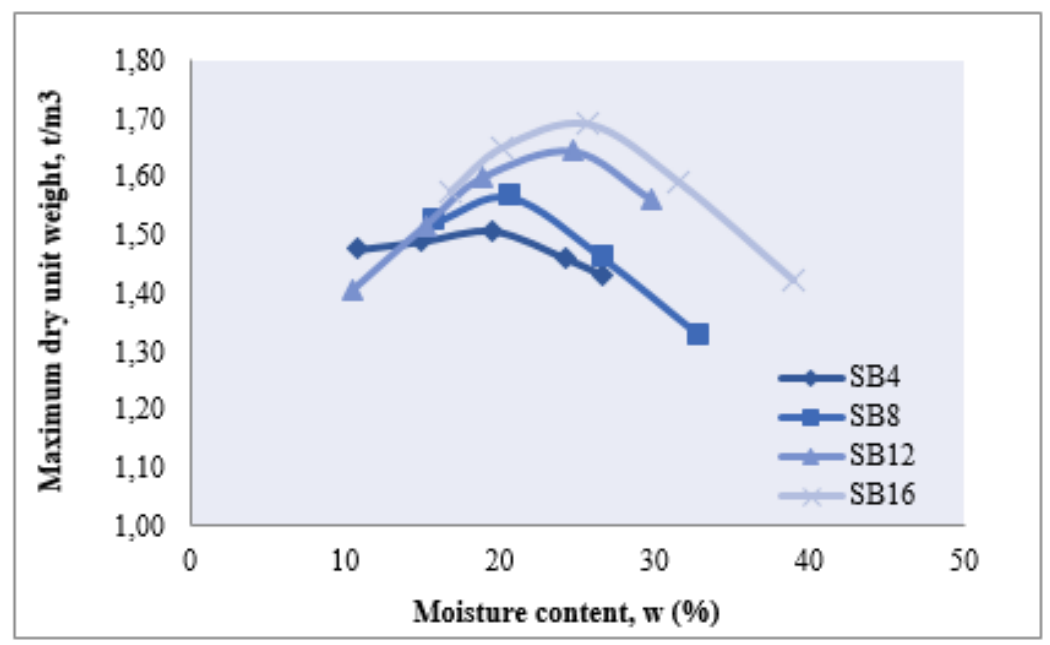

Figure 2. Compaction curves of sand-bentonite mixtures (Number in mixture code is bentonite content)

Sand-bentonite mixtures were stabilized with $3,6,9 \%$ pozzolanic cement and 5, 10, 15, $20 \%$ class C fly ash by weight at optimum water content of sand-bentonite mixtures. The diameter and length of specimens were 50 and $100 \mathrm{~mm}$, respectively. For every mixture, two specimens are prepared and the average of the results of strength tests were used in evaluations. All the specimens were stored in a curing room having a temperature of $20{ }^{\circ} \mathrm{C}$ and a relative humidity of $95 \pm 5 \%$ for 28 days, ensuring similar environmental conditions during strength gain. Control specimens which were not exposed to freeze-thaw action were then subjected to unconfined compressive strength testing beyond 28 days of 
curing. In order to introduce freeze-thaw effect, the specimens were subjected to 4 hours of freezing $\left(-18 \pm 2{ }^{\circ} \mathrm{C}\right)$ and 20 hours of thawing $\left(5 \pm 2{ }^{\circ} \mathrm{C}\right)$, which corresponds to 1 cycle. Specimens were subjected to 1, 3 and 10 cycles of FTA after 28 days of curing. It should be noted that, the specimens were covered with plastic wrap to prevent loss in moisture content during thawing stage. Specimens were coded, e.g. SB8F5FT1 stands for sand bentonite mixture including $8 \%$ bentonite and $5 \%$ fly ash subjected to 1 freeze thaw cycle after 28 days of curing. Details of specimen labels are below:

$$
\mathrm{S}+\mathrm{B}+\left\{\begin{array}{c}
\text { Bentonite content } \\
(4,8,12 \text { or } 16)
\end{array}\right\}+\left\{\begin{array}{c}
C \\
\text { or } \\
F
\end{array}\right\}+\left\{\begin{array}{c}
\text { Cement content }(3,6 \text { or } 9) \\
\text { or } \\
\text { Fly ash content }(5,10,15 \text { or } 20)
\end{array}\right\}+\mathrm{FT}+\left\{\begin{array}{c}
\text { No. of FT cycles } \\
(0,1,3 \text { or } 10)
\end{array}\right\}
$$

\section{RESULTS AND DISCUSSION}

The results are interpreted by classifying soil mixtures of $4,8,12$ and $16 \%$ bentonite content as SP, SP-SC, SP-SC and SC according to the USCS, respectively. It should be noted that the unconfined compressive strength values of SB4, SB8, SB12 and SB16 mixtures without admixtures were obtained as $22.88,35.46,12.35$ and $12.86 \mathrm{kPa}$, respectively.

\subsection{The effect of Soil Type on Freeze-Thaw Behavior}

The effect of stabilization was markedly apparent in soil mixtures including lower amount of bentonite - SB4 and SB8, corresponding to SP and SP-SC soil types. It was observed that SB4C6 and SB16C6 specimens has shown similar strength behavior after application of freeze-thaw cycles. In specimens containing 9\% cement, freeze-thaw resistance was greater in SP-SC type soil mixtures (Figure 3).
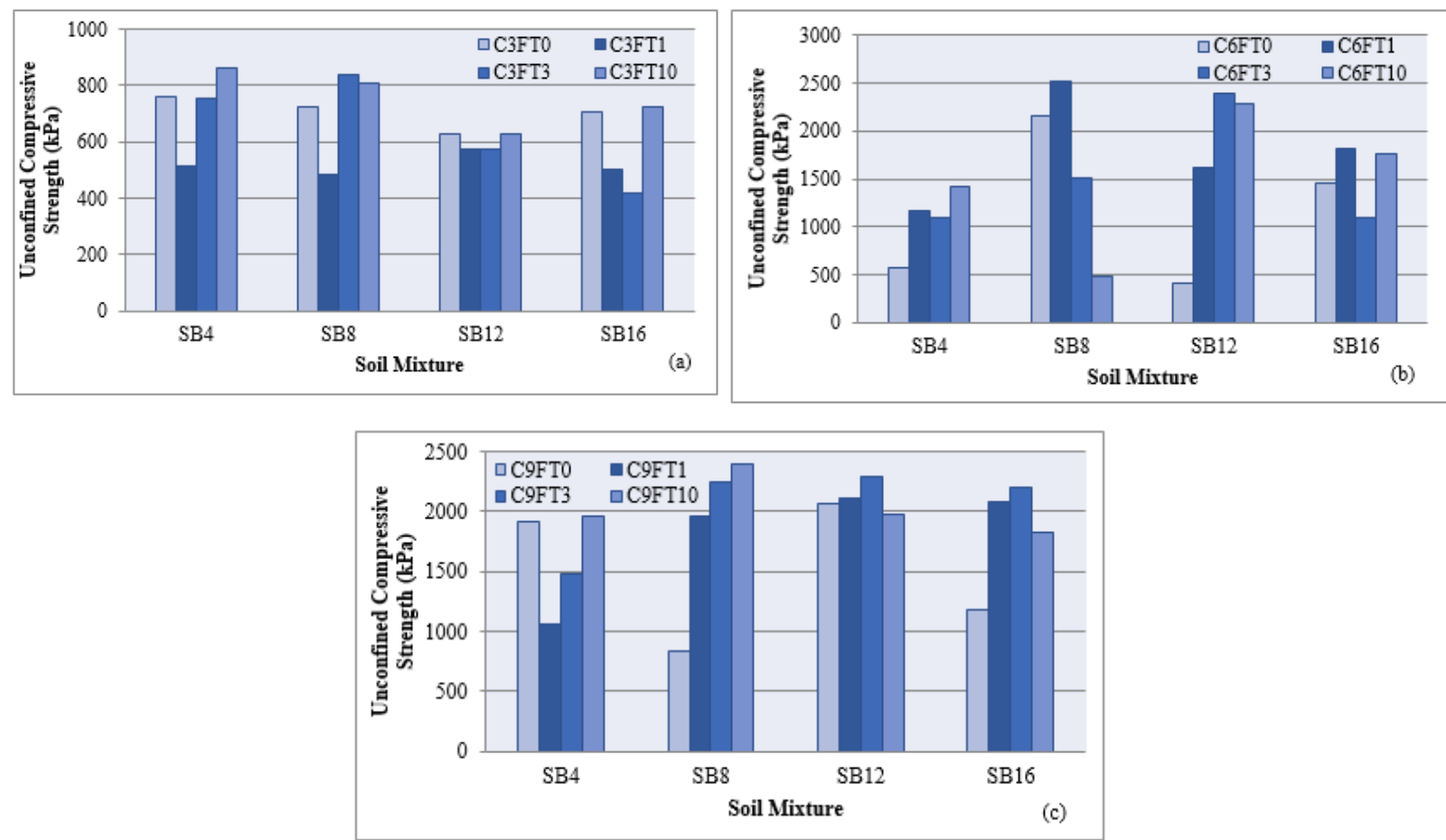

Figure 3. Variation in unconfined compressive strength of specimens stabilized with (a) $3 \%$ (b) $6 \%$ (c) $9 \%$ cement

Analyzing the strength of mixtures of $5 \%$ fly ash content with respect to control specimen, a decrease in strength was observed due to freezing and thawing (Figure 4). For this fly ash content, SC specimens were less severely affected in comparison with those of SP class. Considering 
Sezer et al. / Anadolu Univ. J. of Sci. and Technology A - Appl. Sci. and Eng. 18 (5) - 2017

specimens with $10 \%$ fly ash content, freeze-thaw resistance of SP specimens were the lowest and $\mathrm{SC}$ specimen showed a relatively stable behavior, with increasing number of FT cycles. After 1 cycle, the effect of admixture decreased gradually in SP-SC mixtures with reference to SP class mixtures. It was observed that there was no significant change in strength after 10 cycles for SP-SC and SC mixtures with $10 \%$ fly ash, regardless of soil type.
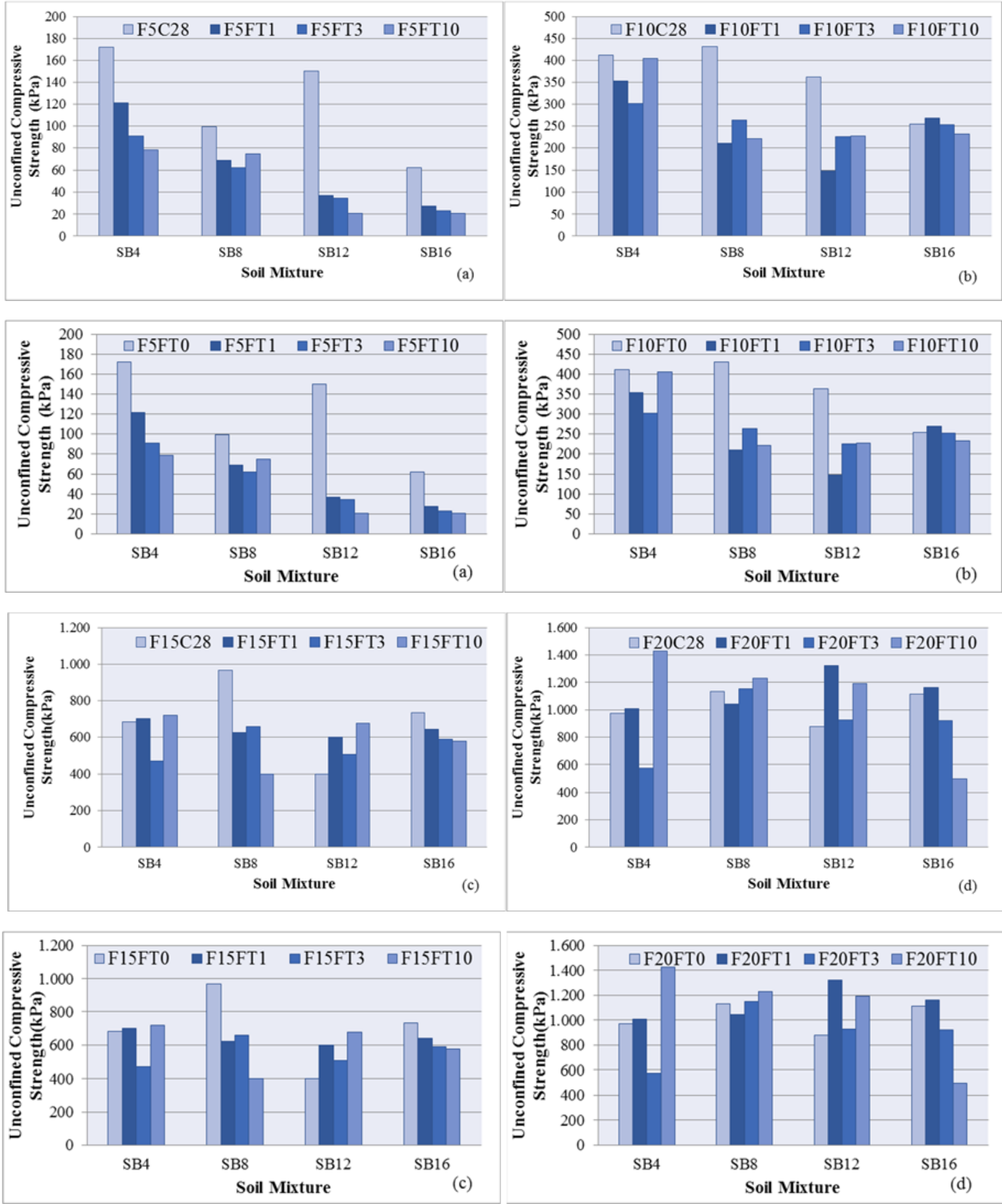

Figure 4. Variation of unconfined compressive strength of specimens stabilized with (a) $5 \%$ (b) $10 \%$ (c) $15 \%$ (d) $20 \%$ fly ash 
Strength of SB8F15 specimens markedly decreased (up to 50\%) as the number of cycles increased. Concerning strength of specimens including $20 \%$ of fly ash, the effect of admixture was less pronounced by the increase in clay content. Accordingly, it was observed that the FTA caused decrease in strength of specimens and SB8 soil mixture was least affected.

\subsection{Effect of Freeze-Thaw Cycles}

Figures 5 and 6 include information about the relationships among unconfined compressive strength and FT cycles for cement and fly ash stabilized mixtures, respectively. Strength of specimens with 3\% cement content decreased. In contrast to this, strength of specimens including $6 \%$ of cement increased after 1 cycle (Figure 5). After 3 cycles of FT, the behavior of all soil types were similar except SB12 soil mixture. The trends of variation in FT behavior of soil mixtures for specimens with 3 and $6 \%$ cement were observed to be different, by increasing number of cycles. Furthermore, it is clear that behavior of SB12 and SB16 specimens were similar.

The strength of specimens stabilized with 5 and $10 \%$ fly ash decreased with increasing number of FT cycles (Figure 6). By changing number of cycles, reduction in strength of SB4F5 was on the order of $25 \%$ and the remaining mixtures were not significantly affected. Referring to strength of control specimens, a decrease was observed in strength of specimens of $10 \%$ fly ash content after 3 cycles, whereas strength of SB8 and SB12 increased up to 33\%, in comparison with results obtained after 1 cycle. For SB4 soil mixtures, a decrease was evident in strength after 1 and 3 FT cycles while an increase was observed after exposing 10 cycles of freeze-thaw. It was noticed that SB16F15 specimens were not remarkably affected by increasing number of FT cycles. With the increase in number of cycles, strength values of SB8F20 specimens increased regularly while strength values of SB16F20 specimens decreased. Experimental results also revealed that, a distinctive behavior for freeze-thaw behavior of SB4 and SB12 mixtures including 20\% fly ash was not evident.

\subsection{Effect of Admixture Content}

SB4 (SP Class) and SB16 (SC Class) mixtures showed an increase in freeze-thaw resistance and strength with increasing cement content. The strength values were regularly increased for SB8FT3 and SB12FT1 specimens. Other soil mixtures did not demonstrate a consistent behavior. Freeze-thaw resistance and strength of specimens stabilized fly ash were increased by increasing admixture content.

The increase in strength of cement stabilized soil mixtures exposed to FT can be explained by ongoing hydration throughout the cycles. During the reactions, water content in the soil matrix is decreased and strength of soil mixture was increased by pore filling action. For this reason, the hydration process is considered to be more effective than the FT mechanism. It is estimated that the increase in strength of fly ash stabilized specimens was observed due to the pozzolanic reaction and the void filling effect of admixture. In addition, specimens with fly ash showed less freeze-thaw resistance. Similar findings were obtained from the results of a stabilization study concerning performance of clay - cement - fly ash mixtures [15]. 
Sezer et al. / Anadolu Univ. J. of Sci. and Technology A-Appl. Sci. and Eng. 18 (5) - 2017
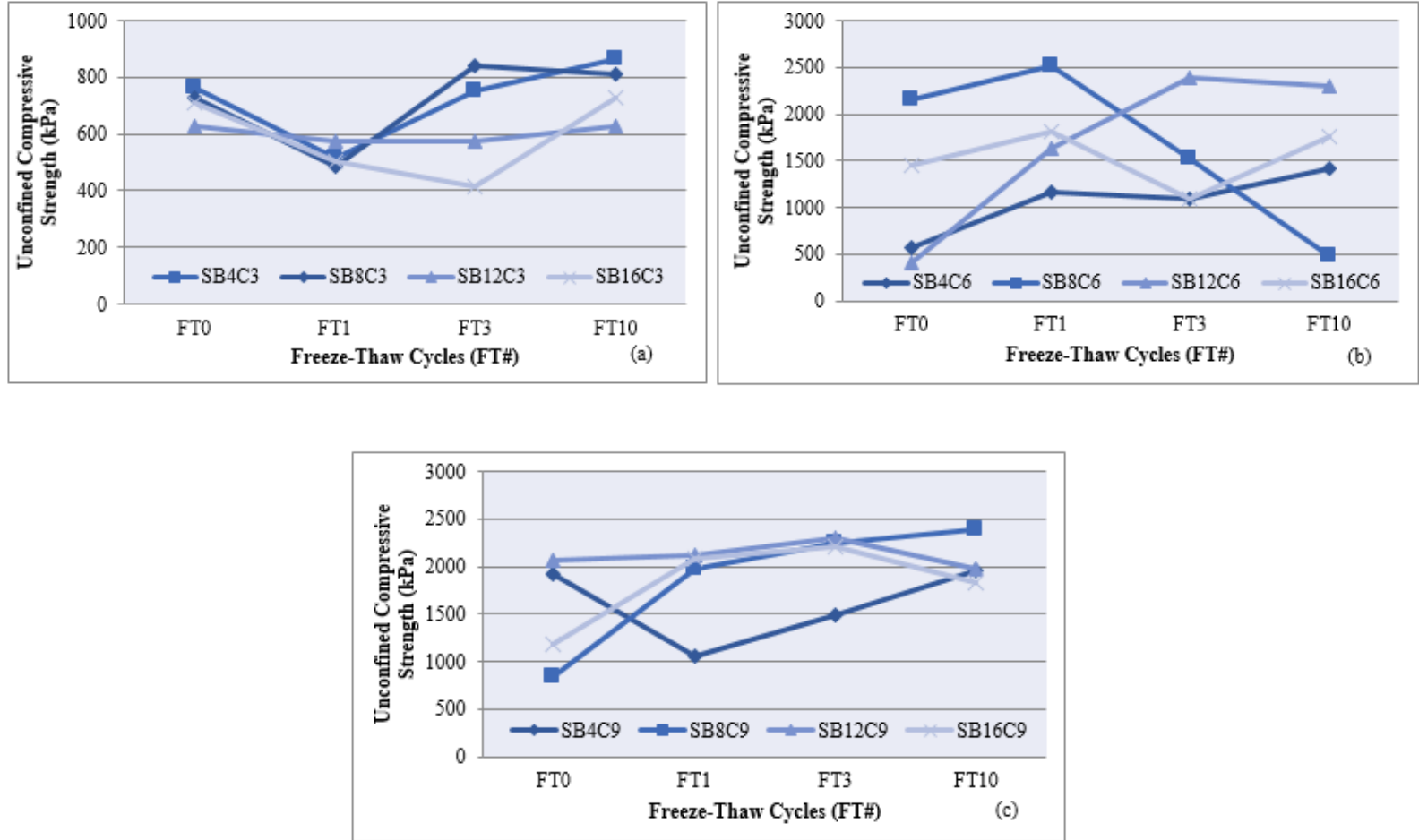

Figure 5. Relationships among FT cycles and unconfined compressive strength of specimens stabilized with (a) $3 \%$ cement (b) $6 \%$ cement (c) $9 \%$ cement
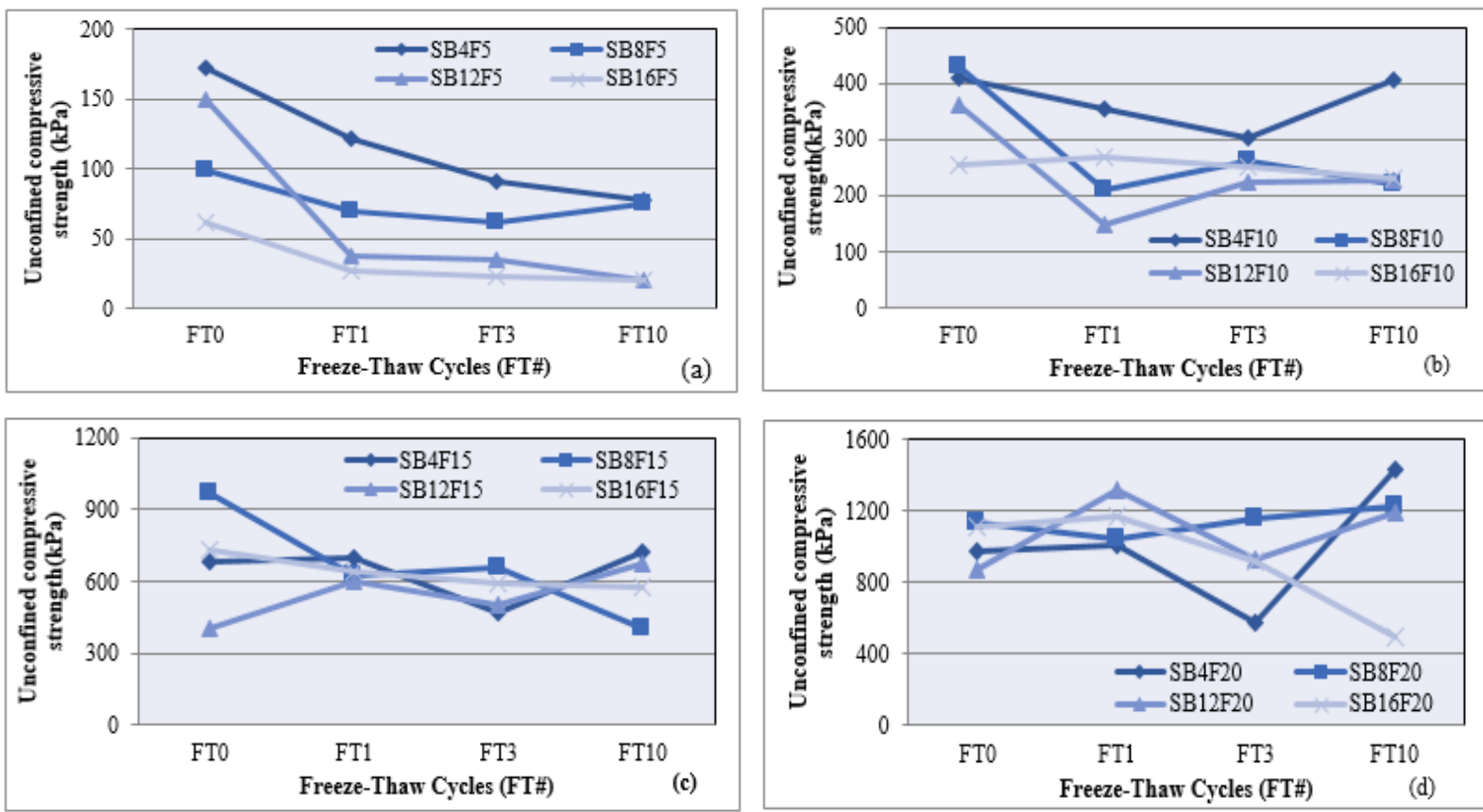

Figure 6. Relationship among number of FT cycles and unconfined compressive strength of mixtures including (a) $5 \%$ fly ash (b) $10 \%$ fly ash (c) $15 \%$ fly ash (d) $20 \%$ fly ash 


\subsection{Secant Modulus $\left(\mathbf{E}_{50}\right)$}

In order to obtain additional information about the stress-strain behavior, particularly on the rigidity of the specimens, the relationships in Figure 7 among unconfined compressive strength and secant modulus were obtained. Effect of increasing bentonite content has no considerable effect on secant modulus of cement stabilized specimens (Figure 7-a). It was also noted that the $\mathrm{q}_{\mathrm{u}}-\mathrm{E}_{50}$ trend of specimens of 4 and $16 \%$ of bentonite content were similar. In addition, increase in cement content caused increase in secant modulus and unconfined compressive strength. In case of fly ash stabilized specimens, unlike the specimens with cement, a regular behavior was obtained indicating a decreasing strength of relationship between secant modulus and unconfined compressive strength by increasing bentonite content (Figure 7-b).
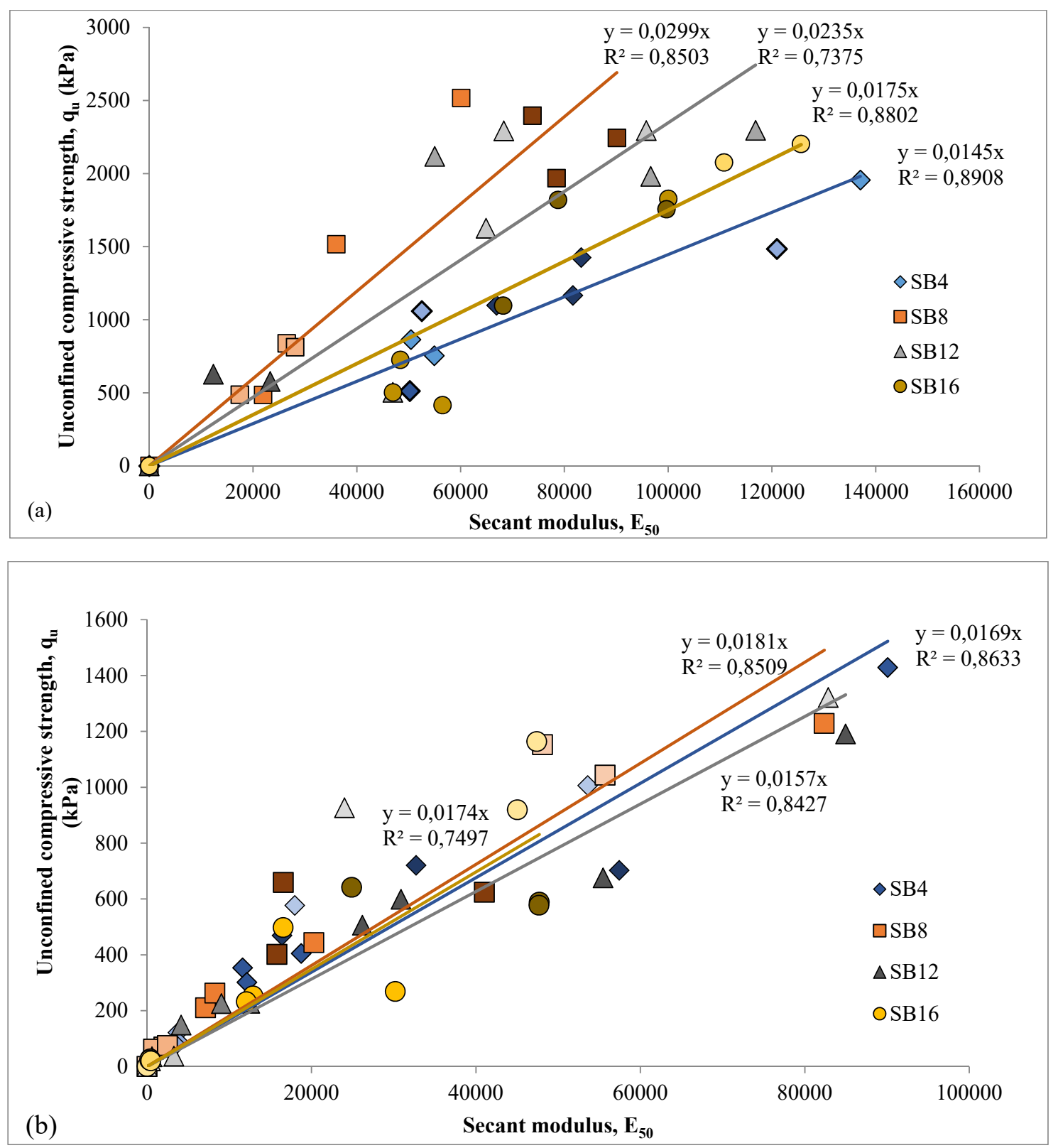

Figure 7. Relationships between secant modulus and unconfined compressive strength (a) Cement stabilized specimens (b) Fly ash stabilized specimens 


\section{CONCLUSIONS}

This study presented an experimental approach for evaluation of freeze-thaw resistance of cement or fly ash stabilized sand/bentonite mixtures, after long curing periods. Following are the conclusions that can be drawn from this study:

a) The behavior of cement and fly ash stabilized sand-bentonite mixtures exposed to freezethaw action were somehow different. Under these F/T conditions, resistance of cement stabilized specimens to $\mathrm{F} / \mathrm{T}$ action was greater than those stabilized with fly ash. Since cement is a better binder in comparison with fly ash, this was an expected result. When strength values of cement stabilized specimens were evaluated, it was concluded that specimens with $9 \%$ cement were least affected by freeze-thaw action. The increase in number of cycles were inconsiderably effective on the freeze-thaw resistance of cement stabilized soil mixtures.

b) The decrease in strength of specimens stabilized with 5\% fly ash was decreased by increasing freeze-thaw cycles. The freeze-thaw resistance and unconfined compressive strength of fly ash stabilized specimens increased with increasing admixture content. If the admixture content in stabilization is lower, a lower $\mathrm{F} / \mathrm{T}$ resistance was obtained, due to decreased amount of resulting hydration products and pore filling effect.

c) The increase in cement content of SP-SC soil mixtures did not cause a significant change in strength values. Strength and resistance of SP and SC specimens were increased by increasing cement content.

d) It was observed that the secant modulus values of cement stabilized specimens after freeze-thaw action were higher than control specimens. Thus, increase in rigidity due to stabilization was more evident in cement stabilized specimens, compared with those stabilized with fly ash. Pozzolanic reactions, formation of hydration products and pore filling effects increase the density, decrease ductility and provide higher strength at smaller axial strains at failure.

e) In order to better understand the freeze-thaw behavior of sand-bentonite mixtures, further effort is needed by carrying out additional experiments including permeability, swelling potential and California Bearing Ratio tests. Particularly, the effect of freezing and thawing periods needs further investigation. Freeze-thaw effects after shorter curing periods must be further evaluated.

\section{REFERENCES}

[1] Ghabaee S. Kireç ile stabilize edilmiş bentonitin kür süresinin mukavemet üzerindeki etkisi. MSc, İstanbul Technical University, Istanbul, Turkey, 2015.

[2] Kilic G. Çimento ile zemin stabilizasyonu. MSc, Yildiz Technical University, İstanbul, Turkey, 2008.

[3] Cetin AY. Yüksek plastisiteli kil zeminlerin alternatif malzemeler ile yüzeysel zemin stabilizasyonu. MSc, İstanbul Technical University, İstanbul, Turkey, 2011. 
Sezer et al. / Anadolu Univ. J. of Sci. and Technology A - Appl. Sci. and Eng. 18 (5) - 2017

[4] Keshawarz MS, Dutta U. Stabilization of South Texas soils with fly ash. In: ASCE National Conference-Fly ash for soil improvement, 24-28 October 1993, Dallas, Texas, USA. New York, USA. Geotechnical Special Publication No:36. pp. 30-43.

[5] Oksuz K. Afşin - Elbistan termik santrali uçucu külünün zemin stabilizasyonunda kullanimi. Msc, Cukurova University, Adana, Turkey, 2006.

[6] Misra A, Biswas D, Upadhyaya S. Physico-mechanical behavior of self-cementing class C fly ashclay mixtures. Fuel 2004; 84: 1410-1422.

[7] Yilmaz Y. Compaction and strength characteristics of fly ash and fiber amended clayey soil. Eng Geol 2014; 188: 168-177.

[8] Unver E. Problemli kil zeminlerin uçucu kül ile iyileştirilmesi. MSc, Osmangazi University. Eskişehir, Turkey, 2015.

[9] Isik A. Sıkıştırılmış zeminlerde donma-çözülme olayinin deneysel incelenmesi. Msc, Istanbul Technical University, İstanbul, Turkey, 2014.

[10] Yarbasi N, Kalkan E, Akbulut S. Modification of the geotechnical properties, as influenced by freeze-thaw of granular soils with waste additives. Cold Reg Sci Tech 2007; 48 (1): 44-54.

[11] Zaimoglu AS, Hattatoglu F, Akbulut RK. Yüke maruz ince daneli zeminlerin donma-çözülme davranış1. Pamukkale Ünv Müh Bil Dergisi 2013; 19(3): 117-120.

[12] Kamei T, Ahmed A, Shibi T. Effect of freeze-thaw cycles on durability and strength of very soft clay soil stabilised with recycled Bassanite. Cold Reg Sci Tech 2012; 82: 124-12.

[13] Liu J, Wang T, Tian Y. Experimental study of the dynamic properties of cement- and limemodified clay soils subjected to freeze-thaw cycles. Cold Reg Sci Tech 2010; 61(1): 29-33.

[14] Erol A. C sınıfı uçucu kül katkılı siltlerin dayanım ve donma-çözülme direncinin deneysel olarak incelenmesi. Msc, Ege University, İzmir, Turkey, 2007.

[15] Horpibulsuk S. Strength and microstructure of cement stabilized clay. In: Kazmiruk, V, editor. Scanning electron microscopy. InTech Open Access, 2012, pp. 439-460. 